\title{
Efficacy of the Presbyterian Church East Africa's Peace Building Strategies in Enhancing Inter-Ethnic Harmony in Kenya
}

\author{
Rev. Julius Guantai Mwamba ${ }^{1}$, Dr. Dickson Nkonge Kagema ${ }^{2}$ \& Dr. Benjamin Mugambi Kanga ${ }^{3}$ \\ 1. PhD Candidate, Department of Humanities, Chuka University, Kenya. \\ 2. Department of Humanities, Chuka University, Kenya \\ 3. Department of Education, Chuka University, Kenya \\ Contact: Dr. Dickson Nkonge Kagema, Chuka University, P.O Box 109-60400 Chuka, Kenya, \\ dicknkonge@gmail.com
}

\begin{abstract}
Ethnic conflicts remain the biggest setback to the development of many African nations today, Kenya included. Different religions and religious organizations have responded in different ways in their effort to address this menace. For instance the Presbyterian Church of East Africa (PCEA) has initiated several peace building strategies aimed at enhancing inter-ethnic harmony in Kenya. Despite the Church's effort in the promotion of harmony in Kenya, inter-ethnic conflicts continue to escalate in various parts of the country, notably Nairobi, Mombasa, Rift Valley and other parts of the country. This study analysed the efficacy of the PCEA peace building strategies in enhancing inter-ethnic harmony in Kenya. The study population was 1,624,345 PCEA members in following presbyteries namely Nakuru west, Nakuru east, Njoro, Elburgon, Laikipia, Eldoret and Mombasa where inter-ethnic conflicts are perceived to be dominant. From this population, a sample size of 384 respondents was obtained using Kathuri and Pals table of 1993. Simple random sampling was used to select the 384 respondents. The study used the descriptive survey research design and the instruments for data collection were questionnaires for the church elders and members, structured interview guide for church ministers and Focus Group Discussions (FGD's) for the victims. The main findings were that the use of sermons; pastoral care and counselling; Bible study; peace building workshops; prayer movements; mainstreaming of Church standing groups; policy development by the PCEA's General Assembly, lobbying and having a Peace desk which the PCEA has been employing as strategies to foster fostering inter-ethnic harmony in Kenya have not been effective. It is important that ways and means are explored to make the Strategies and Programmes employed by religions, religious organizations, Para-religious organizations, the government and other stakeholders in enhancing inter-ethnic harmony in Kenya and other parts of Africa effective.
\end{abstract}

Key terms: Kenya, Religious Organizations, Presbyterian Church of East Africa, Peace Building Strategies, Inter-ethnic Harmony

DOI: $10.7176 /$ RHSS/9-16-06

Publication date: August $31^{\text {st }} 2019$

\section{Introduction}

Since the end of the Cold War in 1980s, the world has witnessed an increasing number of inter-ethnic conflicts as well as other forms of conflicts ranging from religious, ethnic among others. In Africa, ethnic conflict is inherently a problem that requires effective peace building strategies to ensure ethnic tolerance and cohesion (Lynch, 2011). In Kenya, for example, there has been a marked increase in ethnic conflicts in the recent times (Onyebadi\&Oyedeji, 2011). Since independence, Kenyan politics have been guided by ethnic politicking and competition, hence ethnic conflicts in 1992, 2002 and climaxed by the 2007/08 post-election violence which had a repugnant effect. The conflicts in Kenya are multiple and overlapping resulting from a range of factors including ethnic intolerance; historical injustices; border conflicts; ethno-regionalist sentiments and political party zoning; radicalisation; competition over land and other resources; proliferation of small arms; weak security; poverty, underdevelopment, and marginalisation. Inter-communal violence risks being increased by competition over the fruits of devolution and elite manipulation of local communities (Ombaka, 2015; Dowd \& Raleigh, 2013; Halakhe, 2013; Sharamo, 2014; Boone, 2011).

The Presbyterian Church of East Africa (PCEA), in particular, has engaged in peace building initiatives in Kenya after the 2007/2008 post-election conflict Kenya (Mbugua, 2011). In doing this, the PCEA has had several strategies. Some of the strategies that are used by PCEA to bring forth Peace building and reconciliation are Dialogue, Co-ordination, Reconciliation, Participation, Training, Advocacy, Networking, Facilitation, Negotiation, Mediation and Problem Solving Workshops. (Mbugua, 2011). The PCEA actively undertakes a role towards peace building in all her Presbyteries through evangelism by using sermons and Biblical studies, 
having a peace desk, mainstreaming standing groups in the Church, pastoral care and guidance (Wainaina, 2015). It does this by spreading the Gospel of Christ which carries the message of salvation and belonging to one big family-the family of Christ. Another strategy employed by the PCEA in enhancing inter-ethnic harmony is having weekly prayer meetings. For instance, PCEA congregations in Eldoret have been holding weekly overnight inter-denominations prayer meetings (Keshas) to pray for the town of Eldoret (Njoroge, 2011). The Church has initiated home 'Churches'/cells that are helpful in creating a bond of togetherness and a sense of belonging-to-one-family amongst the members irrespective of their tribal affiliations. Church visitations and having a peace desk are among other strategies employed by the PCEA in peace building. This activity is usually coordinated by the Church ministers in the presbyteries. The PCEA in Laikipia West District has similarly set up a network of districts. The districts are group of families which meet once a week for prayers and sharing on any emergency issues. These districts channel their problems to the congregation (Njoroge, 2011). The congregation may help the victims directly if they have the resources or may contact the parish and presbytery for assistance.

The foregoing show that the PCEA has been at the forefront in fostering peace in their areas of operation using various methods, particularly submission and confession, mediation, dialogue, peace workshops and peace visits. In spite of this, conflicts recur, a factor that compelled us to undertake this study so as investigate whether the strategies employed by the PCEA are effective or not.

This study was guided by the the Liberal Peace Theory advanced by Lederach (1997). Through the Liberal Peace Theory, the concept of peace building and reconciliation is understood as a process that takes place along approaches of conflict resolution. Wafula (2014) asserts that reconciliation is a condition that goes beyond the conflict, however, the approach adopted in this study focuses on reconciliation as the last challenge to reach in order to sort out a conflict. As long as you have people previously confronted not reconciled, the conflict is still there and violence is likely to flourish anytime. Liberal peace theory thus underscores that reconciliation is fundamental in conflictive contexts in order to get people living together in long term peace. Lederach (1997) lauds the expansion of conflict resolution to include alternative dispute resolution, mediation, conciliation, violence prevention, early warning systems, community reconciliation, nonviolent peacekeeping, trauma healing, second-track diplomacy, and problem-solving workshops. Proponents of liberal peace theory argue that whatever the policy and whatever the reasons whether religious or secular, there are powerful reasons to want citizens to support peace building initiatives. According to the proponents of liberal peace theory, religious actors should use the modicum of religious influence at their disposal to foster peace, justice and the common good of society. This view is premised on the standard view that citizens should support basic liberal commitments proffered by the Church such as the rights to religious decorum, forgiveness, and tolerance to promote inter-ethnic harmony.

More generally, proponents of Liberal Peace Theory maintain that a citizen may rely on his/ her religious convictions to determine which individual actions promote justice and the common good and may support interventions aimed at achieving the same even if such intervention may have no plausible material rationale. This implies that people in communities where inter-ethnic conflict are prevalent abide by certain epistemic requirements precisely because they support peace building initiatives in order to achieve normative propriety of their favoured outcomes. If this is right, then, religious leaders have an obligation to aspire to persuade their religious compatriots by appeal to religious reasons to support peace building initiatives implemented by the Church.

\section{Methodology}

This study adopted the descriptive survey research method employing a mixture of qualitative and quantitative methods in many phases in the research process. The study was conducted in seven selected PCEA presbyteries in Kenya where inter-ethnic conflicts have been reported dominant namely Nakuru west, Nakuru East, Njoro, Elburgon, Eldoret, Laikipia and Pwani.The target population was 1,624,345 members from the presbyteries chosen for this study namely; Nakuru, Eldoret, Laikipia and Pwani comprising of 103 ministers, 1620 church elders and 1622622 Ordinary Church members. The presbyteries were chosen because they cover conflict areas namely Nakuru, Eldoret, Laikipia and Mombasa. The sample for this study was determined by using a Table for determining the size of randomly selected sample adapted from Kathuri and Pals (1993). Kathuri and Pals (1993), recommend a sample of 384 from a population exceeding one million. Out of the 384 recommended by Kathuri and Pals (1993) the study selected 4 Church ministers 38 Church elders and 342 Church members who were affected by ethnic conflicts totalling to 384 respondents. Of the 384 , only $350(91.1 \%)$ were available to provide with the information used in this study.

Stratified simple random sampling was employed to select 4 Church ministers, 38 Church elders. The clergy and Church elders were considered key informants as they are the ones overseeing the implementation of peace building 
initiatives in the area and also are charged with the responsibility of providing pastoral care and are trusted in preaching peace. The elders are in charge of a group of families referred to as district or home cells and are responsible for their home cell's pastoral needs.

To ensure the inclusion criteria were followed, the researchers interrogated church members that consented to take part in the survey. Church members were targeted to provide information for this study as some of them might have been affected by the conflicts and are being involved in peace building strategies initiated by the PCEA. According to Creswell and Garrett (2008), a researcher needs to choose participants based on certain criteria that allows him/her to arrive at the participants who are knowledgeable in the aspects that the study variables seeks to investigate.

The study collected data using questionnaires for the Church elders and members, in-depth interview guide for the Church ministers (the presbytery moderator and the clerk) and Focus Group Discussions for the Church members who are victims.Saldana (2011) says that using multiple data gathering methods guarantees a wider spectrum of diverse perspectives for analysis and representation. Harris (2010) argues that limitation of one data collection method can be addressed by an additional method and that multiple data collection methods enhance credibility and trustworthiness.

\section{Efficacy of PCEA Strategies in Enhancing Inter-Ethnic Harmony in Kenya}

The purpose of this study was to investigate the efficacy of peace building strategies of PCEA, in enhancing inter-ethnic harmony in Kenya. This was necessary to highlight strengths of the Presbyterian Church in the process of sustainable peace building. The study evaluated peace building strategies of PCEA in peace building taking into account strategies such as Church Sermons, Pastoral care and counselling, Bible study, Peacebuilding workshops, Prayer movements, mainstreaming of various PCEA standing groups in peace building, Strategic direction for the Church formulated by general assembly regarding peace building, lobbying and having a peace desk.

A 5-point Likert scale was used for the respondents to rate the degree to which they agreed or disagreed with the peace building strategies used by PCEA in enhancing inter-ethnic harmony. Likert-type scaling requires multiple statements (items) to define the content and meaning of the construct being quantified. The score yielded by a Likert-type scale is a composite (summation) of the responses to the multiple items comprising the scale or subscale, not responses to single items. The data gathered using questionnaires were collated, encoded into the computer and statistically treated using the Statistical Package for Social Sciences (SPSS) version 21. The responses are captured in Table 1 below.

The data in Table 1 show that sermons $($ Mean $=1.58)$, pastoral care and counselling $($ Mean $=1.73)$, inter-ethnic vocational Bible study (Mean =1.91), peace building workshops (Mean 2.24), prayer movements $($ Mean $=2.36)$, mainstreaming peace building in various PCEA standing groups (Mean $=1.82$ ), strategic directions provided by the GA on peace building (Mean $=2.41)$, lobbying $($ Mean $=2.10)$ and peace desk $($ Mean $=1.88)$ as peace building strategies employed by PCEA are not effective. The results of the weightened mean of the responses measured on a five point Likert scale show that all had a mean less than 2.5.

From the findings it can be inferred that all the peace building strategies employed by the PCEA in enhancing inter-ethnic harmony in Kenya that include sermons, pastoral care and counselling, inter-ethnic vocational Bible study, peace building workshops, prayer movements, mainstreaming peace building in various PCEA standing groups of the Church, strategic directions provided by the General Assembly on peace building, lobbying and having peace desk manned by Justice Peace and Reconciliation desk at the PCEA head office in Nairobi have not been effective. The responses are discussed in details below. 


\section{Table 1}

\section{Efficacy of PCEA Peace Building Strategies}

\begin{tabular}{|c|c|c|c|c|c|c|}
\hline & 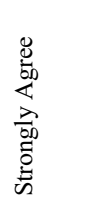 & 总 & 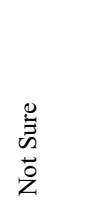 & 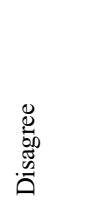 & 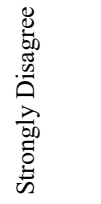 & $\underset{\Xi}{\stackrel{\Xi}{\Xi}}$ \\
\hline $\begin{array}{l}\text { Church Sermons have brought positive attitude } \\
\text { change towards peaceful coexistence among } \\
\text { inter-ethnics }\end{array}$ & $3(1)$ & $6(2)$ & $22(6)$ & $132(38)$ & $187(53)$ & 1.58 \\
\hline $\begin{array}{l}\text { Pastoral care and counselling of inter-ethnic } \\
\text { conflicts victims has contributed to recovery and } \\
\text { restoration of victims of inter-ethnic conflict } \\
\text { thus enhancing inter-ethnic harmony }\end{array}$ & $7(2)$ & $16(5)$ & $27(8)$ & $127(36)$ & 173(49) & 1.73 \\
\hline $\begin{array}{l}\text { Inter-ethnic vocational Bible study has enabled } \\
\text { victims of inter-ethnic conflict to reconcile } \\
\text { hence enhancing inter-ethnic harmony }\end{array}$ & $22(6)$ & $14(4)$ & $38(11)$ & $113(32)$ & $163(47)$ & 1.91 \\
\hline $\begin{array}{l}\text { Peace-building workshops have been useful in } \\
\text { imparting peace building skills and advocacy } \\
\text { thereby enhancing inter-ethnic harmony }\end{array}$ & $36(10)$ & $24(7)$ & $64(18)$ & $91(26)$ & 135(39) & 2.24 \\
\hline $\begin{array}{l}\text { Prayer movements to address inter-ethnic } \\
\text { conflicts have facilitated healing and hope for } \\
\text { the future for the victims }\end{array}$ & $28(8)$ & $18(5)$ & $96(27)$ & $118(34)$ & $90(26)$ & 2.36 \\
\hline $\begin{array}{l}\text { Mainstreaming peace-building in various PCEA } \\
\text { standing groups has brought about } \\
\text { inclusion of all the society's groups towards the } \\
\text { agenda of maintaining inter-ethnic harmony }\end{array}$ & $6(2)$ & $14(4)$ & $32(9)$ & $144(41)$ & $154(44)$ & 1.82 \\
\hline $\begin{array}{l}\text { Strategic direction for the church formulated by } \\
\text { general assembly regarding peace building has } \\
\text { ensured harmony in delivery of peace building } \\
\text { strategies in all thereby enhancing inter-ethnic } \\
\text { harmony }\end{array}$ & $18(5)$ & $37(11)$ & $78(22)$ & $156(45)$ & $61(17)$ & 2.41 \\
\hline $\begin{array}{l}\text { Lobbying the government to address inter-ethnic } \\
\text { conflicts within NCCK has led to development } \\
\text { of supportive policy has enhanced inter-ethnic } \\
\text { harmony }\end{array}$ & $16(5)$ & $32(9)$ & $66(19)$ & $94(27)$ & $142(40)$ & 2.10 \\
\hline Peace desk & $22(6)$ & $4(1)$ & $48(14)$ & $113(32)$ & $163(47)$ & 1.88 \\
\hline
\end{tabular}

\subsection{Church Sermons}

With regard to Church sermons 187 (53\%) strongly disagreed that Church Sermons had brought positive attitude change towards peaceful coexistence among inter-ethnic communities. The rest $132(38 \%)$ disagreed, 22(6\%) were not sure that Church Sermons had brought positive change, 6(2\%) agreed while 3(1\%) strongly agreed. These findings imply that sermons implemented by PCEA as a method of peace building have not been effective in ensuring inter-ethnic harmony in Kenya as cited by the majority $(53 \%)$ of the Church members. This is tandem with Wafula (2014) findings that preaching by use of sermons was not a strategic avenue for peace building in multi-religious nations like Kenya.

\subsection{Pastoral Care and Counselling}

The results further show that the majority $173(49 \%)$ of the Church members strongly disagreed while $127(36 \%)$ disagreed that pastoral care and counselling programme implemented by the PCEA was effective in enhancing 
inter-ethnic harmony. Only $7(2 \%)$ strongly agreed, while $16(5 \%)$ agreed as $27(8 \%)$ remained non-committal. Thus, it can be interpreted to mean that PCEA pastoral care and counselling has not been effective in bringing about lasting peace as cited by the majority (49\%) of the Church members who took part in this study. Similarly, the ineffectiveness of the strategy was supported by $127(36 \%)$ of the members of the PCEA.

\subsection{Inter-EthnicVocational Bible Study}

The results of this study show that the majority 163(47\%) of the Church members strongly disagreed while $113(32 \%)$ disagreed that inter-ethnic vocational Bible study had enabled victims of inter-ethnic conflict to reconcile hence enhancing inter-ethnic harmony. Conversely, 26(6\%) strongly agreed while 14(4\%) agreed and 38)11\%) were neutral). The findings of this study imply that inter-ethnic Bible study used as a peace building strategy by the PCEA has seldom achieved the purpose of ensuring inter-ethnic harmony in Kenya. This is supported by the majority of the Church elders and ordinary members that participated in this study. While $113(32 \%)$ also affirmed the ineffectiveness of the strategy in achieving the intended goal of ensuring inter-ethnic harmony, a section of the study population was of the contrary opinion by indicating that the strategy was effective as cited by $26(6 \%)$ who strongly agreed while $14(4 \%)$ agreed. However, $38(11 \%)$ of the members did not either disagree or agree. This observation is supported by Bauer and Traina (2011) and Wink (2010) who established that Bible study groups have failed to consolidate lasting peace in the community.

The results of this study further show that, the mean response from all the responses as measured on five point Likert scale was 1.91. This implies that inter-ethnic vocational Bible study spearheaded by the PCEA has not been effective as a strategy of enhancing interethnic harmony in Kenya. This is in tandem Powers (2010) findings that though Bible study is a useful tool to engage different people in peace building, the method has not achieved much due to ideological differences on doctrines and beliefs. Interreligious peace building strategies such as inter-ethnic vocational Bible study is a vital facet of peace building in societies with multiple religious' affiliations. It is an avenue that can be explored further to achieve tangible development. It is clear that only the construction of a peaceful interpretation of Scripture can bring the necessary knowledge for identifying the ways in which violent interpretations can be countermanded and peaceful interpretations further developed.

This study interviewed 4 Church ministers who apparently supported this finding. Kimani (2018) did note that even though the Church had programmes for inter-ethnic vocational Bible study, the strategy was not well structured. Similarly, Muibei (2018) reported that the Church has been struggling hard to bring on board interethnics to vocational Bible study aimed at enhancing reconciliation and galvanizing inter-ethnic harmony through more acceptable to the non-PCEA Christian populace especially in the Eldoret presbytery. These comments indicate that vocational Bible study spearheaded by PCEA as a peace building strategy was not effective.

\subsection{Peace Building Workshops}

The results presented in Table 9 indicate that 135(39\%) of the Church members strongly disagreed, 91(26\%) disagreed, 64(18\%) were neutral, 24(7\%) agreed while 36(10\%) strongly agreed that peace building workshops have been useful in stopping inter-ethnic conflicts. The results here imply that peace building workshops implemented by the PCEA have not been useful in stopping inter-ethnic conflicts in Kenya. Based on the findings, it was evident that the majority $135(39 \%)$ of the Church members strongly disputed the effectiveness of this strategy, while $91(26 \%)$ also dissented, 64(18\%) remained non-committal and 24(7\%) felt that the strategy was somehow effective and 36(10\%) strongly agreed that the strategy was effective. In support of this, Muibei (2018) indicated that peace building workshops have failed to consolidate any meaningful gains because in most cases participants fail to implement peace building strategies imparted to them probably due to apathy or rigidity to embrace change.

The PCEA initiated a strategy of mitigating inter-ethnic conflict through engaging the conflicting communities in peace building workshops. The strategy was developed as a policy for peace building to enhance inter-ethnic harmony. The peace building workshops aim to serve as a model of inclusive development processes where participants come together as equals to bring about changes in attitudes, behaviours, systems and structures that build peace as a result of processes and linkages initiated in these workshops. In particular, to build an acceptance and an understanding of the link between change and the potential of change to contribute either to violence or to peace, to develop long term relationships and linkages between development actors at different levels and from different sectors; to acknowledge a common responsibility and building a commitment to a common way forward. The peace building workshops further aim at creating an environment where open and honest discussion takes place and building relationships that can be sustained beyond the workshop. Whereas the 
value of peace building workshops are well documented, the success of the strategy in achieving its core objective of promoting inter-ethnic harmony in Kenya remained unknown before this study was conducted.

The study purposely ventured into finding out what has been achieved so far by peace building workshops. The results of this study show that the mean response was 2.24 that correspond to disagree on the Likert scale. This implies that peace-building workshops have not been very useful in galvanizing inter-ethnic harmony. Conversely, peace building initiatives that do not produce any positive impact must be disconnected or reinvented. In concrete terms, this means giving the strategy a critical evaluation and organizing the strategy in a manner that is effective to respond to inter-ethnic conflict constructively.

\subsection{Prayer Movements}

The results in Table 1 further shows that the majority 118(34\%) of the Church members disagreed that prayer movements initiated by the PCEA to enhance inter-ethnic harmony were useful. On a similar vein, 90(26\%) strongly disagreed, 96(27\%) were non-committal, 28(8\%) strongly agreed while $18(5 \%)$ agreed. The results of this study show that prayer movements implemented by the PCEA have not succeeded in bringing about lasting peace in Kenya. Indeed, this is reflected by the majority $118(34 \%)$ of the Church members who disagreed that prayer movements initiated by the PCEA to enhance inter-ethnic harmony were useful. This was also reflected by the $90(26 \%)$ of the respondents who on the other hand strongly disagreed as opposed to $96(27 \%)$ who remained non-committal on this and $28(8 \%)$ who strongly agreed and $18(5 \%)$ who agreed that the strategy was effective. The results of this study are congruent with Njoroge (2011)'s findings that despite the Church having members and groups of families who meet once a week for prayers and sharing on any emergences, peace building efforts have seldom yielded much.

In the views of one of the presbytery moderators, prayer is the key that unlocks all the storehouses of God's infinite grace and power. All that God is, and all that God has, is at the disposal of the prayer. But we must use the key. Prayer can do anything that God can do, and as God can do anything, prayer is omnipotent (Warutere, 2018). Thus, prayer is a powerful constituent of religious norms and values that addresses the most profound existential issues of human life. Prayer opens the heart not only to a deep relationship with God, but also to an encounter with others, marked by respect, understanding, esteem and love. This spirituality, with roots in, for example, the dignity of every person, active nonviolence, reconciliation and the gift of diversity is richly influenced by the PCEA tradition in which prayer movements have been initiated.

\subsection{Mainstreaming Church Standing Groups}

The results of this study also indicate that mainstreaming various Church groups in peace building was not efficacious either. Out of the 350 Church members that took part in this study $154(44 \%)$ strongly disagreed, $144(41 \%)$ disagreed, $32(9 \%)$ were neutral, 14(4\%) agreed while $6(2 \%)$ strongly agreed. The findings can be interpreted to mean that inter-ethnic harmony in Kenya has not been achieved through PCEA's intervention of mainstreaming Church Standing Groups in peace building. This is according to 154(44\%) who strongly disagreed with the sentiment that the strategy was effective, 144(41\%) who also disagreed, 32(9\%) remained neutral, that is, they could not explicitly say the strategy worked or not while $14(4 \%)$ of the respondents agreed the strategy was effective and $6(2 \%)$ that strongly agreed the strategy was working.

This study interrogated the efficacy of mainstreaming various PCEA standing groups in peace-building. This was aimed at establishing whether inclusion of all the Church groups in peace building initiatives has enhanced her agenda of maintaining inter-ethnic harmony in Kenya. The vision of mainstreaming various PCEA standing groups in peace-building was to propagate peace-building ministries among the churches and civil society organizations through consultations, seminars, cell groups, seminary courses, and other modes of communication and education. An analysis from the participants' responses show that the mean responses was 1.82 measured at a 5 -point Likert scale corresponding to disagree.

This implies that mainstreaming various PCEA standing groups in peace-building has seldom achieved its goal of enhancing inter-ethnic harmony. Drawing on findings, it can probably be argued that the weakness of mainstreaming PCEA standing groups in peace building may be as a result of two factors. First, some groups or individuals may have reservations about working with actors of a different religion or those opposed to the intersection of religion and peace building. Second, religious peace actors may be perceived to be proselytizing, by actively seeking to attract religious membership or conversion. Though there is instrumental value in integrating Church standing group's in peace building efforts, it is important to stress that progress towards mainstreaming of Church groups in peace building goals is neither a given outcome nor will it follow a linear 
process of change. It is therefore important that PCEA re-thinks her strategies in mission work and especially on peace building.

\subsection{Policy Directions on Peace by the PCEA General Assembly}

The result of this study show that the majority $156(45 \%)$ of the Church members disagreed while $61(17 \%)$ strongly disagreed that policy directions on peace provided by the PCEA General Assembly (GA) to the presbyteries have been effective in enhancing inter-ethnic harmony through bolstering lasting peace. Conversely, 37(11\%) agreed and 18(5\%) strongly agreed while 78(22\%) remained non-committal. The findings imply that the policy directions on peace building provided by the GA to her members in a cascaded framework have not been effective in ensuring inter-ethnic harmony in Kenya. This is manifested in the responses from the majority $156(45 \%)$ of the Church members who indicated their resentments. A similar resentment was reflected by $61(17 \%)$ who strongly disagreed that policy directions on peace building provided by the General Assembly of PCEA to the presbyteries have been effective in enhancing inter-ethnic harmony through bolstering lasting peace. The responses from $37(11 \%)$ and $18(5 \%)$ who either agreed or strongly agreed was not significant to tilt the balance, while $78(22 \%)$ appeared not to affirm or disapprove that policy directions on peace building provided by the General Assembly to her members were effective in ensuring inter-ethnic harmony or not.

The PCEA General Assembly formulates and provides policy directions on peace building and conflict management to its members in the respective presbyteries in Kenya. It does so by providing direction to all her congregational members and affiliates (Kaania, 2018). The General Assembly is the Church's supreme legislative, administrative and judicial authority, and like all other subordinate church bodies and congregations, is governed by the church constitution (Njoroge, 2011). Under the policy slogan "Peace building is the believers' calling" the General Assembly of PCEA has provided direction to the respective presbyteries to work with communities, Churches and institutions in order to avert, transform, mediate and resolve conflicts.

The General Assembly practice of developing and providing policy directions on peace building has not been effective in enhancing inter-ethnic harmony in Kenya (Mean = 2.41). A verbatim response from Gichunge (2018) supports this finding when he reported that " Most congregations have no rules or structure for helping people negotiate or collaborate, towards achieving peace ... I have not yet been in a Church that has a decent set of programmes on how to deal with inter-ethnic conflict mitigation in this region".

The current study postulates that although religious structures are strategically placed in ensuring continued cohesion in the area, they lack adequate capacity. Peace building strategies must be coherent and tailored to the specific needs of the communities concerned, based on national ownership and should comprise a carefully prioritized, sequenced and therefore relatively narrow set of activities aimed at achieving the objectives. This information is useful to state and non-state actors as well as institutions seeking to foster sustainable peace through enhancement of inter-ethnic harmony in Kenya. The disconnect between numerous peace building interventions strategies among conflicting ethnic communities and its dismal impact should form a basis of interest for future studies.

\subsection{Lobbying through National Council of the Churches of Kenya (NCCK)}

This study sought to find out if PCEA strategy of using the National Council of Churches of Kenya (NCCK) to reach out and influence the government to create legislation on peace building has achieved this goal. The results obtained show that the majority $142(40 \%)$ of the Church members strongly disagreed, $94(27 \%)$ disagreed, $66(19 \%)$ were neutral on this while $32(9 \%)$ and $16(5 \%)$ agreed and strongly agreed respectively. The findings of this study imply that though the PCEA has used NCCK to lobby the government to come up with effective mechanisms to mitigate conflict, the strategy has seldom achieved this goal. This can be attested by looking at the at the respondents' perceptions regarding the matter. Going by this, it was evident that the majority 142(40\%) of the Church members strongly disagreed that PCEA's strategy of using the NCCK to reach out and influence the government to create legislation on peace building has achieved any tangible deliverables. On a similar vein, $94(27 \%)$ disagreed, $66(19 \%)$ were neutral on this while $32(9 \%)$ and $16(5 \%)$ agreed and strongly agreed respectively. In a study of the struggle against "Ethnic Clashes" in Kenya, Klopp (2009) established that the moral leadership and organization of the National Council of Churches of Kenya (NCCK) is one of the few key counter forces to the dangerous violence experienced in society.

This Church-led peace-building approach is legitimised in part by the Church's moral and spiritual authority, providing her with a certain leverage to mitigate conflict. Furthermore, the Church enjoys a special niche to lobby government and contribute to policy changes. Specifically, the study sought information on whether 
reaching out to the government singly or within NCCK to address inter-ethnic conflicts has led to development of supportive policy for enhancing inter-ethnic harmony in Kenya. Founded in 1913 during the United Missionary Conference, NCCK has vast experience in the area of peace building and conflict management. By using Church networks as a platform, different actors have tried to involve in peace-building processes in Kenya. This Church-led peace-building approach is legitimised in part with reference to the unique position the Church holds locally in these societies, and in part because their leaders are held in high esteem nationally and transnationally. The summated scores of the responses (mean $=2.10$ ) show that the corresponding Likert inference is disagree. This therefore leads to the conclusion that the PCEA strategy of using NCCK to reach out and influence the government to create legislation on peace building has not completely achieved this goal.

A verbatim response obtained from Ndambiri (2018) show that for NCCK, policy advocacy was and continues to be a strategy for long term healing and reconciliation. The Council was involved in influencing the passage of pieces of legislation such as the Truth, Justice and Reconciliation Act, National Cohesion and Integration Act, The Constitutional Review Act of 2008, and the Witness Protection Act in the Kenyan Parliament.

The other facet of advocacy that the NCCK was involved in as indicated by Murang'a (2018) was in the domain of transitional justice. Additionally, as part of advocacy, NCCK is involved in monitoring the process of the Kenya National Dialogue and Reconciliation Project (KNDR) as parts of efforts to ensure that the reform process was underway following the signing of the National Accord on February 28, 2008, a process that laid the framework for a coalition government for the sake of national unity. Among other issues, the Council continued to lobby the government to address the plight of internally displaced persons in areas such as compensation and resettlement.

On a similar vein, Mwangi (2018) indicated that despite challenges faced, NCCK has played a great role for the conflict management of 2007 election violence in Kenya. In general, Mwangi asserts that since religious institutions have a deep understanding of the local context and to all levels of power community, nation-giving them the ability to work to address conflicts successfully on multiple levels. Mwangi (2018) continues to point that the PCEA has been partnering with the government through NCCK in the national process of reconciliation, supplementing the government's top-down strategy with bottom-up approaches.

\subsection{Peace Desk}

The study further investigated the impact of having a peace desk on peace building and enhancing inter-ethnic harmony. The results of this study indicate that the majority $163(47 \%)$ strongly disagreed, 113(32\%) disagreed, $48(14 \%)$ were neutral while $4(1 \%)$ agreed and $22(6 \%)$ strongly agreed that the peace desk at head office manned by the JPRC has been helpful in enhancing inter-ethnic harmony. The implication of these findings is that though the PCEA has a peace desk managed by Justice, Peace and Reconciliation Committee (JPRC) at the head office, the desk has not been vibrant as it used to be when the JPRC was first formed. Indeed, the lack of efficacy of the peace desk is supported by the majority $163(47 \%)$ of the Church elders and ordinary members who strongly disagreed, that it was effective, 113(32\%) disagreed, 48(14\%) were neutral while 4(1\%) agreed and 22(6\%) strongly in agreement.

This is congruent with Call and Cousens (2008) findings that much of the Church's work for peace, especially at the local level, is not well known or well understood. Thus, the Peace Desk aims to stimulate a more systematic sharing, mapping and analysis of the best practices in peace and conflict management in the Church. The results obtained show that the summated scores of the responses $($ mean $=1.88)$ correspond to disagree on a 5-point Likert scale. This therefore leads to the conclusion that the PCEA strategy of using a Peace Desk aimed at connecting peace builders from different regions and partner with other ecumenical bodies and religious organization in order to build and deepen relationships and enhance the exchange of ideas has not completely achieved this goal.

Responses from Church members were triangulated with interview responses from the Presbytery moderators. A large percentage of those interviewed noted that the Church has been involved in a number of peace building strategies. For example, Mburu (2018) explained that peace committees under the aegis of the Church play a significant role in facilitating consultative peace dialogues; act as alert systems to prevent conflict before they happen; and also raise awareness within and between the warring communities. There are several concerns however which were raised touching on the role, the structure and capacity of these peace committees. With regard to their roles, many presbytery moderators felt that the peace committees do not have defined roles and as a result their impact at the grassroots level where the actual planning and carrying out of conflict particularly by the locals has not been realized. 
Results of the Focus Groups indicate that other peace building strategies employed by the PCEA in ensuring inter-ethnic harmony in Kenya included inter-faith dialogue and missions, spearheading interfaith council of clerics and initiating religious caucuses such as "Chemchemi Ya Ukweli". Inter-religious Council of Kenya (IRCK) is the leading interfaith body, whose central mission is to foster peace and interfaith dialogue, aimed at promoting tolerance and understanding among faith communities in Kenya through mobilizing joint actions for socioeconomic development. A prominent example of IRCK's approach and activities was a two-day conference it organized in November 2014 on Youth for Peaceful Coexistence in Kenya. The event brought together students from institutions of higher education across Kenya to encourage interfaith conversation on countering violent extremism and radicalization among youth. Invited religious leaders from all faiths and peace practitioners interacted with the students through presentations and active dialogue. Participants sought answers as to how to engage youth proactively and actively on radicalization issues without causing tension or distrust.

The results of the one Focus Group held in Pwani Presbytery reveal that religious leaders formed Coast InterFaith Council of Clerics (CICC) as a tool for peace building which works to promote peace in the coastal region of Kenya. CICC, a registered trust, has eight member organizations including: Catholic Archdiocese of Mombasa and SUPKEM. CICC grew originally out of a series of meetings organized by the Coastal Peace Initiative after 1997 violence in Likoni killed over 100 people over several weeks. Local faith leaders, Christian, Muslim, traditional, and Hindu came together in an open dialogue to identify the causes of the conflict and coordinate a faith-led peace effort. This led the religious leaders to realize that lasting peace can be achieved only through efforts that engage all ethnicities and religions, combining dialogue with different forms of action. According to the results of Focus Group Discussion held at St. Margaret PCEA in Pwani presbytery, it was noted that CICC has cultivated a trusting and respectful environment through a practice of open dialogue, where all member organizations willingly work together towards peace building. CICC undertakes conflict analysis in the region and works to address issues of religious intolerance, negative ethnicity and prejudice, political power struggle, poor governance, inequitable resource sharing, land ownership and utility, impunity and corruption, and unresolved historical injustices that frequently precipitate inter-ethnic conflicts.

The study further established that CICC clergy engage communities to discuss peace from a faith perspective and to diffuse community conflicts as they arise. A distinctive feature is its effort to work through all the member organizations, allowing CICC to reach communities from diverse ethnic and religious backgrounds. Their Interfaith Youth Project, for instance, aimed to combat youth radicalization in the Kwale by teaching youth entrepreneurship, bookkeeping, peace building mechanisms, and food processing as a way to forge strong interethnic and interfaith bonds and develop tangible skills to earn sustainable incomes. These are crucial for keeping youth away from violence. From this continuum, the Kwale Interfaith Youth Association (KIYA) emerged and now serves as an umbrella organization that helps coordinate youth peace building activities in Kwale with a nourishing micro-credit program. Despite this, the communities living in the coastal region have continued to experience sporadic waves of inter-ethnic conflicts. Perhaps a fuller picture of why conflicts persist even with scaled efforts such as engaging inter-faith groups in conflict intervention. This information is particularly important when attempting to gain a deeper understanding of how religion works and the many ways that it matters to people in relation to peace building efforts by the Church.

Besides CICC, "Chemchemi Ya Ukweli" is also relevant in Pwani presbytery. Chemichemi focuses on enhancing social transformation through active nonviolence, community policing, civic education, research, networking, and interreligious dialogue to achieve the rule of law, public safety, harmony and self-development. The organization has Catholic roots but has developed into an inclusive interfaith movement, linking Christians, Muslims, Hindus, and Bahai's. Its nonviolence programs promote a culture of peace, empower peace activists, and create a support system that helps activists engage with their communities. Its holistic approach to peace involves a broad array of programs including agriculture, community policing, governance, and civic education, all designed to address systemic violence and reach out to historically oppressed communities, including women and youth. Chemichemi promotes interfaith dialogue to promote social cohesion, working with and supporting interfaith networks in communities throughout Kenya.

In the words of Munyoroku (2018), the core of Chemichemi's peace building efforts is its training program. The training introduces community leaders to the concept of active non-violence and encourages them to think about how they can foster it within their communities. Interested leaders then join a more intensive, five-day training where attendees are expected to share their new skills and knowledge with their own communities. Chemichemi relies on its trained peace building activists to identify and recruit new trainees to help sustain the training system. Lederach (2015) argues that religious organizations and institutions provide useful structures for reaching out to the broader population and engaging them in the peace building process. Creating vertical and 
horizontal networks for peace, such as between secular and religious peace builders or from the local to international level, changes the incentives for parties to a conflict, prompting them to end violent conflict and support peace. In a similar vein Muriithi (2018) reported that religious actors can generate or channel pressure for warring parties to agree to peace, address the drivers of the conflict and implement conflict transformation and reconciliation programming.

\section{Conclusion}

Religion acts as an agent of peace, justice and reconciliation. In this regard, religions in Kenya as in other parts of the world have employed peace building strategies that are aimed at promoting peace in areas that have been hit by conflicts. For example, the Presbyterian Church of East Africa (PCEA) has been involved in the promotion of peace, justice and reconciliation in Kenya. This has been through various strategies that are employed by the PCEA's leadership to ensure that peace, justice and reconciliation are achieved in violence prone areas where PCEA is dominant. What is worrying is the fact that in spite of these efforts by the PCEA and other religious organizations, conflicts continue to be experienced in many parts of Kenya. From this study, it is clear that the cause of this is the fact that the strategies employed by the Church are not effective. In this regard, ways and means have to be employed to ensure that these strategies are effective. This is the only way in which peace, justice and reconciliation can be enhanced in Kenya and the rest of Africa. Religion is vital in bringing forth justice, peace and reconciliation but the methods employed have to be effective.

\section{REFERENCES}

Amodu, L. O. (2012). Community relations strategies and conflict resolution in the Niger Delta: A study of three major oil companies (Doctoral dissertation, Covenant University).

Anderson, D. \&Lochery, E. (2008). Violence and exodus in Kenya's Rift Valley, 2008: predictable and preventable? Journal of Eastern African Studies, 2(2), 328-343.

Anderton, C. H. (2016). Datasets and trends of genocides, mass killings, and other civilian atrocities. Economic aspects of genocides, other mass atrocities, and their prevention, 52-101.

Bandyopadhyay, S., \& Green, E. (2013). Nation-building and conflict in modern Africa. World Development, 45, 108-118.

Boone, C. (2011). Politically allocated land rights and the geography of electoral violence: The case of Kenya in the 1990s. Comparative Political Studies, 44(10), 1311-1342.

Botha, A. (2013). Assessing the Vulnerability of Kenyan Youths to Radicalisation and Extremism. Institute for Security Studies Papers, 2013(245), 28.

Cheng, J. T., Tracy, J. L. \& Henrich, J. (2010). Pride, personality, and the evolutionary foundations of human social status. Evolution and Human Behavior, 31(5), 334-347.

Cheng, J. Y. (2012). Convincing the world of China's tradition to pursue universal harmony. Journal of Chinese Political Science, 17(2), 165-185.

Creswell, J. W., \& Garrett, A. L. (2008). The "Movement" of Mixed Methods Research and the Role of Educators. South African Journal of Education, 28(3), 321-333.

Dowd, C. and Raleigh, C. (2013). Sahel State Political Violence in Comparative Perspective. Stability: International Journal of Security and Development, 2(2),

Ettah, M. A. (2013). Cultural Pluralism as a Source of Political Instability in Kenya: A Critical Analysis. A Master of Arts in International Conflict Management to the Institute of Diplomacy and International Studies, University Of Nairobi, Kenya.

Gichunge, P. (2018). Reverend of PCEA, Interviewed on October $27^{\text {th }} 2018$ at PCEA Saint Margaret Church, Mombasa.

Halakhe, A. B. (2013). R2P in Practice": Ethnic Violence, Elections and Atrocity Prevention in Kenya. Global Center for the Responsibility to Protect: Occasional Paper Series No, 4.

Harris, R. (2016). Research in Education Evidence-Based Inquiry. Boston: Pearson Education.

Kaania, P. (2018). Reverend of PCEA, Interviewed on October $27^{\text {th }} 2018$ at PCEA Saint Margaret Church, Mombasa.

Kathuri, N. J., \& Pals, D. A. (1993). Introduction to Educational Research. Njoro Kenya.

Kagema, D. N. (2012). Developing Church leaders in Africa for reliable leadership: A Kenyan perspective. Dutch Reformed Theological Journal= NederduitseGereformeerdeTeologieseTydskrif, 53(3, 4), 229-240.

Kaimba, G. K., Bernard, K. N., \& Abdi, Y. G. (2011). Effects of cattle rustling and household characteristics on migration decisions and herd size amongst pastoralists in Baringo District, Kenya."Pastoralism: Research, Policy and Practice 1(1): 1. 
Kariuki, J. K. (2016). Peace Building among the Urban Poor of Mathare Informal Settlement in Nairobi County: The Interventions of the Anglican Church of Kenya, Diocese of Nairobi 1999-2009. Amaster of Arts (Religious Studies) Of Kenyatta University.

Kimani, M. (2018). Reverend of PCEA, Interviewed on December $17^{\text {th }} 2018$ at PCEA AyubKinyua, Eldoret.

Lederach, J. P. (1997). Sustainable Reconciliation in Divided Societies. Washington, DC: USIP.

Lederach, J. P. (2015). Sustainable Reconciliation in Divided Societies. Washington, DC: USIP.

Lynch, G. (2011). I Say to You: ethnic politics and the Kalenjin in Kenya. University of Chicago Press.

Mbugua, J. K. (2011). Drivers of insecurity in Somalia: mapping contours of violence. International Peace Support Training Centre.

Mburu, J. (2018). Reverend of PCEA, Interviewed on October $27^{\text {th }} 2018$ at PCEA Saint Margaret Church, Mombasa.

Muibei, D. (2018). PCEA Church Elder, Interviewed on December $17^{\text {th }} 2018$ at PCEA AyubKinyua Church, Eldoret.

Munyoroku, J. (2018). Reverend of PCEA, Interviewed on October $27^{\text {th }} 2018$ at PCEA Saint Margaret Church, Mombasa.

Muranga, S. (2018). Reverend of PCEA, Interviewed on December $15^{\text {th }} 2018$ at PCEA Saint Ninian's Church, Nakuru.

Murithi, J. (2018). Reverend of PCEA, Interviewed on December 17 2018 at PCEA AyubKinyua, Eldoret.

Mwangi, J. (2018). Reverend of PCEA, Interviewed on December $15^{\text {th }} 2018$ at PCEA Saint Ninian's Church, Nakuru.

Njoroge, E. M. (2011). Church's Approaches to Peacebuilding and Reconciliation in Ethnic Conflict Areas in Kenya: A Case Study of Laikipia West District (Doctoral dissertation, Ph. D. Thesis, Kenyatta University, Kahawa, Nairobi).

Nthambiri, T. (2018). Reverend of PCEA, Interviewed on December $15^{\text {th }} 2018$ at PCEA Saint

Ombaka, D. M. (2015). Explaining Kenya's insecurity: The weak state, corruption, banditry and terrorism. International Journal of Liberal Arts and Social Science, 3(3), 11-26.

Onyebadi, U. \&Oyedeji, T. (2011). Newspaper coverage of post political election violence in Africa: An assessment of the Kenyan example. Media, War \& Conflict, 4(3), 215-230.

Powers, G. F. (2010). Religion and Peace Building. Strategies of Peace: Transforming Conflict in A Violent World, 317-352.

Saldana, H. (2011). Techniques of Writing Proposals and Research Reports in Education and Social Science Research Methods: Maseno. Kenya: Kanezja Publishers.

Sharamo, R. (2014). The politics of pastoral violence: a case study of Isiolo County, Northern Kenya. Future Agricultures Consortium Working Paper, 95.

Sharamo, R. (2014). The politics of pastoral violence: A case study of Isiolo county. Northern Kenya.

Wafula, N. M. (2014). The Role of the Church in Promoting Reconciliation in 2008-2013 Post-Election Violence Kenya (Doctoral Dissertation, University of Nairobi).

Wainaina, E. N. (2015). Factors Influencing Women's Non Participation In Church Administrative Leadership In The Presbyterian Church Of East Africa, Milimani Presbytery, Nairobi County; 19082012 (Doctoral Dissertation, Kenyatta University.

Warutere, P. (2018). Reverend of PCEA, Interviewed on December $18^{\text {th }} 2018$ at PCEA PCEAMuruai Church, Laikipia. 